Original Article

\title{
Peran Keluarga terhadap Penurunan Tingkat Kecemasan Lanjut Usia
}

\author{
Dewi Puspa Cipta Utami \\ RS Bunda Margonda \\ Jln. Margonda Raya No.28, Pondok Cina, Kecamatan Beji, Kota Depok, Jawa Barat 16424 \\ Email: dedewpupus@gmail.com
}

\begin{abstract}
Introduction: The role of the family is the specific behavior expected by someone in the family member. Anxiety is a fear that is not clear and is not supported by the situation.

Objective: To Know the Relationship of Family Role to the Level of Anxiety in the Elderly in Hamlet 01 Kukusan Beji-Depok

Method: The research method uses analytics with a cross-sectional approach. The study population was 288 people with a sample of 81 respondents using the Slovin formula. In the sampling technique using cluster sampling.

Results: The results showed that the respondents with a bad family role as many as 41 (50.6\%) anxiety levels of the middle aged were $59(72.8 \%)$. The results of statistical tests using the chi-square test indicate that there is a significant or significant relationship between the role of the family and the level of anxiety of the elderly with a value of $\mathrm{p}$-value 0.01 .

Conclusion: It was concluded that there was a relationship between the role of the family and the level of anxiety of the elderly in the Hamlet 01 Kelurahan Kukusan Beji District Depok City.
\end{abstract}

Keywords: anxiety, elderly, the role of family

Editor: Yt

Hak Cipta:

(C2021 Artikel ini memiliki akses terbuka dan dapat didistribusikan berdasarkan ketentuan Lisensi Atribusi Creative Commons, yang memungkinkan penggunaan, distribusi, dan reproduksi yang tidak dibatasi dalam media apa pun, asalkan nama penulis dan sumber asli disertakan. Karya ini dilisensikan di bawah Lisensi Creative Commons Attribution Share Alike 4.0 Internasional. 


\section{Pendahuluan}

Menua atau menjadi tua adalah suatu keadaan yang terjadi di dalam kehidupan manusia. "Menua" (menjadi tua) adalah proses menghilangnya secara perlahan kemampuan jaringan untuk memperbaiki diri/mengganti diri dan mempertahankan struktur dan fungsi normalnya sehingga tidak dapat bertahan terhadap jejas (termasuk infeksi) dan memperbaiki kerusakan yang diderita. ${ }^{1}$ Jumlah lanjut usia (diatas 60 tahun) pada tahun 2000 adalah $11 \%$ dari seluruh jumlah penduduk dunia $\left( \pm 605\right.$ juta). ${ }^{2}$ jumlah penduduk lanjut usia di Indonesia pada tahun 2010 adalah 18.037.009 jiwa dari 237.641.326 jiwa jumlah seluruh penduduk. ${ }^{3}$ Pada tahun 2015, jumlah penduduk lanjut usia di Indonesia 22,6 juta jiwa dari total populasi penduduk 225 juta jiwa, serta akan mencapai sekitar 48,2 juta jiwa dari total populasi penduduk 305,7 jiwa pada tahun 2035 (Depkes, 2016). Begitu pula di Jawa Barat, jumlah lansia mengalami kondisi yang sama terjadi peningkatan, tahun 2015 jumlah lansia di Jawa Barat sebanyak 46.709.569 jiwa. $^{4}$

Keluarga merupakan support system utama bagi lansia dalam mempertahankan kesehatannya. Peranan keluarga dalam perawatan lansia antara lain menjaga atau merawat lansia, mempertahankan dan meningkatkan status mental, mengantisipasi perubahan sosial ekonomi serta memberikan motivasi dan memfasilitasi kebutuhan spiritual bagi lansia. Setiap anggota keluarga mempunyai struktur peran formal dan informal. Struktur kekuatan keluarga meliputi kemampuan berkomunikasi, kemampuan adalah kecemasan, depresi, insomnia, dan demensia. ${ }^{5}$ Keluarga untuk saling berbagi, kemampuan sistem pendukung diantara anggota keluarga, kemampuan perawatan diri, kemampuan menyelesaikan masalah. Dukungan keluarga mempunyai pengaruh yang besar dalam kehidupan lansia. Lansia serta emosional akan merasa diperhatikan, mendapat saran atau kesan yang menyenangkan pada dirinya dan prilaku suatu kegiatan atau aktifitas yang dapat diamati atau tidak dengan adanya dukungan keluarga. ${ }^{6}$

Dukungan keluarga terbagi atas 4 jenis yaitu: dukungan emosional, dukungan penghargaan, dukungan informasional, dan dukungan intrumental. Dukungan emosional yaitu dukungan yang diberikan keluarga dalam bentuk kasih sayang pada lansia. Dukungan penghargaan yaitu dukungan yang diberikan keluarga dalam bentuk umpan balik, menghargai, mendengarkan keinginan dan harapan lansia. Dukungan informasi yaitu dukungan yang diberikan keluarga dalam bentuk informasi dan pengambilan keputusan. Dan yang terakhir adalah dukungan instrumental yaitu dukungan yang diberikan keluarga dalam bentuk bantuan memberikan tenaga, dana, maupun penyediaan waktu dan transportasi bagi lansia. ${ }^{7}$ Keempat dukungan keluarga diatas berpengaruh pada tingkat kecemasan seseorang. Kecemasan adalah perasaan takut yang tidak jelas dan tidak didukung oleh situasi. Gangguan kecemasan tidak dianggap bagian dari proses penuaan normal, tetapi perubahan dan tantangan yang lansia hadapi (seperti penyakit kronis, gangguan kognitif, gangguan emosional) dapat berkontribusi pada perkembangan gejala dan gangguan kecemasan. ${ }^{8}$ Perubahan mental atau psikis pada lanjut usia dapat berupa sikap yang semakin egosentrik, mudah curiga, bertambah pelit atau tamak bila memiliki sesuatu. Perubahan psikologis yang paling sering muncul dan sering dialami oleh lansia. $^{8}$

Hasil studi pendahuluan yang dilakukan peneliti tanggal 10 Oktober di wilayah RW. 01 Kelurahan Kukusan Kecamatan Beji Kota Depok didapatkan data bahwa hasil wawancara terhadap kader setempat mengatakan setiap sebulan sekali diadakan posyandu khusus lansia yang dilakukan oleh ibu-ibu PKK. Hasil observasi bahwa didapatkan 45 lansia di RT.01, 44 lansia di RT.02, 39 lansia di RT.03, 35 lansia di RT.04, 40 lansia di RT.05, 40 lansia di RT.06, 
45 lansia di RT.07. dari masing-masing RT lansia terlihat banyak menyendiri dan ditinggal keluarganya. Ada juga lansia yang tinggal hanya berdua dengan pasangannya tanpa adanya dampingan keluarga.

Hasil observasi saat melakukan studi pendahuluan masih terlihat beberapa lansia yang mengalami kecemasan dengan perilaku sering melamun, merasa dirinya diasingkan oleh keluarga dan masyarakat dan takut akan datangnya kematian. Pengolahan data dilakukan melalui proses editing data, coding, cleaning data dan processing. Berdasarkan latar belakang diatas maka peneliti tertarik melakukan penelitian yang berjudul "Hubungan Peran Keluarga dengan Tingkat Kecemasan Lansia di wilayah RW. 01 Kelurahan Kukusan Kecamatan Beji Kota Depok Tahun 2018"

\section{Metode}

Penelitian yang digunakan adalah analitik dengan desain cross sectional karena peneliti mencoba menggali bagaimana dan mengapa banyak lansia yang mengalami kecemasan dan bagaimana peran keluarga berpengaruh dalam kecemasan lansia. Penelitian ini dilakukan untuk mengetahui peran keluarga dengan tingkat kecemasan lansia.

Populasi adalah keseluruhan subjek penelitian yang diterapkan oleh peneliti untuk dipelajari kemudian ditarik kesimpulannya. ${ }^{9}$ Populasi dalam penelitisn ini adalah semua lansia yang berada di wilayah RW. 01 Kelurahan Kukusan Kecamatan Beji Kota Depok yang berjumlah 288 orang. Sampel adalah bagian dari jumlah dan karakteristik yang dimiliki oleh populasi. ${ }^{9}$ Sampel penelitian ini adalah lansia di wilayah RW. 01 yang karakteristiknya sama dengan lansia di RW. 01 kelurahan Kukusan Kecamatan Beji Kota Depok dengan menggunakan Slovin dan cluster sampling yang dilakukan dengan cara memilih sampel dari kelompok-kelompok atau unit-unit yang terkecil. Sampel yang terlibat dalam penelitian ini adalah lansia yang mengalami kecemasan sebanyak 81 sampel di wilayah RW. 01 Kelurahan Kukusan Kecamatan Beji Kota Depok.

Data yang dipergunakan dalam penelitian ini dengan mempergunakan data demografi berupa nama responden, jenis kelamin. Menggunakan data primer berupa lembar kuesioner. Jenis skala pengukuran yang digunakan adalah skala ordinal.

\section{Hasil}

Tabel 1. Distribusi Frekuensi Peran Keluarga $(n=81)$

\begin{tabular}{ccc}
\hline Peran Keluarga & $\begin{array}{c}\text { Frekuensi } \\
(\mathbf{F})\end{array}$ & Persentase (\%) \\
\hline Tidak Baik & 41 & 50,6 \\
Baik & 40 & 49,4 \\
Total & 81 & 100 \\
\hline
\end{tabular}

Hasil penelitian menunjukan frekuensi peran keluarga di wilayah RW. 01 Kelurahan Kukusan Kecamatan Beji Kota Depok sebagian besar dikatakan tidak baik sebanyak 41 $(50,6 \%)$. 
Tabel 2. Distribusi Frekuensi Kecemasan Lansia (n=81)

\begin{tabular}{ccc}
\hline Kecemasan Lansia & $\begin{array}{c}\text { Frekuensi } \\
(\text { F) }\end{array}$ & Persentase (\%) \\
\hline Ringan & 4 & 4,9 \\
Sedang & 59 & 72,8 \\
Berat & 18 & 22,2 \\
Total & 81 & 100 \\
\hline
\end{tabular}

Hasil penelitian menunjukan frekuensi tingkat Kecemasan Lansia di wilayah RW. 01 Kelurahan Kukusan Kecamatan Beji Kota Depok sebagian besar kecemasan dalam kategori sedang sebanyak $59(72,8 \%)$.

\section{Analisis Bivariat}

Tabel 3. Hubungan Peran Keluarga Dengan Tingkat Kecemasan Lansia di wilayah RW. 01 Kelurahan Kukusan Kecamatan Beji Kota Depok Tahun 2018

\begin{tabular}{|c|c|c|c|c|c|c|c|c|c|}
\hline \multirow{3}{*}{ Peran Keluarga } & \multicolumn{6}{|c|}{ Kualitas Tidur } & & & \multirow{3}{*}{ Nilai $P$-Value } \\
\hline & \multicolumn{2}{|c|}{ Ringan } & \multicolumn{2}{|c|}{ Sedang } & \multicolumn{2}{|c|}{ Berat } & \multicolumn{2}{|c|}{ Total } & \\
\hline & $\mathbf{F}$ & $\%$ & $\mathbf{F}$ & $\%$ & $\mathbf{F}$ & $\%$ & $\mathbf{F}$ & $\%$ & \\
\hline Tidak Baik & 0 & 0,0 & 32 & 78,0 & 9 & 22,0 & 41 & 100 & 0,01 \\
\hline Baik & 4 & 10,0 & 27 & 67,5 & 9 & 22,5 & 40 & 100 & \\
\hline
\end{tabular}

Hasil chi-square diperoleh responden peran keluarga tidak baik dan tingkat kecemasan lansia sedang sebanyak $32(78,0 \%)$ sedangkan responden peran keluarga baik dan tingkat kecemasan ringan sebanyak $4(10,0 \%)$. Hasil uji statistik didapatkan nilai $p$-value $0,01<\mathrm{a}(0,5)$ maka $\mathrm{H} 0$ ditolak dan dinyatakan bahwa ada hubungan antara peran keluarga dengan tingkat kecemasan lansia di wilayah RW. 01 Kelurahan Kukusan Kecamatan Beji Kota Depok.

\section{Pembahasan}

\section{Mengidentifikasi peran keluarga terhadap lansia di wilayah RW. 01 Kukusan Beji- Depok.}

Berdasarkan tabel 1 distribusi frekuensi Peran Keluraga di wilayah RW. 01 Kelurahan Kukusan Kecamatan Beji Kota Depok sebagian besar dikatakan Tidak baik sebanyak 41 $(50,6 \%)$. Peran keluarga adalah tingkah laku spesifik yang diharapkan oleh seseorang didalam konteks anggota keluarga. Jadi peranan keluarga adalah yang menggambarkan seperangkat perilaku interpersonal, sifat, dan kegiatan yang berhubungan dengan individu didalam posisi dan situasi tertentu. ${ }^{10}$ Peran keluarga dalam perawatan lansia keluarga merupakan support system yang utama bagi lansia dalam mempertahankan kesehatannya. Peran keluarga dalam perawatan lansia antara lain menjaga atau merawat lansia, mempertahankan dan meningkatkan 
status mental, untuk mengantisipasi perubahan sosial ekonomi, dan juga untuk memberikan motivasi dan menfasilitasi kebutuhn spiritual bagi lansia. ${ }^{11}$

Menurut asumsi peneliti, peran keluarga yang diterapkan di wilayah RW. 01 Kelurahan Kukusan Kecamatan Beji Kota Depok belum berperan dengan baik karena komunikasi yang terjalin antara keluarga dengan lansia tidak efektif karena kesibukan dari masing-masing keluarga sehingga lansia merasa kesepian dan kurang berinteraksi sehingga Lansia yang memasuki tahapan akhir memiliki emosional yang tidak stabil.

\section{Mengidentifikasi Tingkat Kecemasan Lansia di wilayah RW. 01 Kelurahan Kukusan Kecamatan Beji Kota Depok.}

Berdasarkan tabel 1 distribusi frekuensi Peran Keluarga di wilayah RW. 01 Kelurahan Kukusan Kecamatan Beji Kota Depok sebagian besar dikatakan Sedang sebanyak 59 (72,8\%).

Penelitian ini sejalan dengan (Aprillia Kartini,2017) yang menyatakan bahwa Kecemasan Lansia di Unit Pelayanan Terpadu Puskesmas wilayah Citereup Bogor yaitu Kecemasan sedang sebesar 32 orang dengan proporsi $(32,5 \%)$ dan frekuensi terendah adalah kecemasan sedang yaitu sebanyak 29 orang dengan proporsi $(31,9 \%)$.Kecemasan adalah perasaan was-was seakan sesuatu yang buruk akan terjadi dan merasa tidak nyaman seakan ada ancaman yang disertai gejala-gejala fisik seperti jantung yang berdebar,keringat dingin dan tangan yang gemetar. ${ }^{12}$

Menurut asumsi peneliti tingkat kecemasan lansia di wilayah RW. 01 Kelurahan Kukusan Kecamatan Beji Kota Depok memiliki tingkat kecemasan yang sedang karena kurangnya teman atau keluarga untuk bercerita sehingga menyebabkan lansia mengalami kecemasan yang kurang baik. Karena dengan bercerita atau berinteraksi dengan teman atau keluarga dapat mengurangi beban yang dirasakan lansia.

\section{Hubungan Tingkat Kecemasan Lansia di wilayah RW. 01 Kelurahan Kukusan Kecamatan Beji Kota Depok.}

Berdasarkan uji statistik hasil chi-square diperoleh responden peran keluarga tidak baik dan tingkat kecemasan lansia sedang sebanyak $32(78,0 \%)$ sedangkan responden peran keluarga baik dan tingkat kecemasan ringan sebanyak 4 (10,0\%). Hasil uji statistik di dapatkan nilai $p$-value $0,01<$ a $(0,5)$ sehingga dapat dinyatakan bahwa ada hubungan antara peran keluarga dengan tingkat kecemasan lansia di wilayah RW. 01 Kelurahan Kukusan Kecamatan Beji Kota Depok.

Penelitian ini sejalan dengan Laili Nur (2009), yang menyatakan bahwa Sebagian besar lansia di Desa Daleman Kecamatan Tulung Kabupaten Klaten mendapatkan dukungan sosial yang rendah, rata-rata lansia di Desa Daleman Kecamatan Tulung Kabupaten Klaten mengalami Tingkat kecemasan dalam kategori sedang, dan terdapat hubungan dukungan sosial dengan tingkat kecemasan pada lansia di Desa Daleman Kecamatan Tulung Kabupaten Klaten. ${ }^{14}$

Peran keluarga adalah tingkah laku spesifik yang diharapkan oleh seseorang didalam konteks anggota keluarga. Jadi peranan keluarga adalah yang menggambarkan seperangkat perilaku interpersonal, sifat, dan kegiatan yang berhubungan dengan individu didalam posisi dan situasi tertentu. ${ }^{15}$ 


\section{Fungsi keluarga}

Friedman, 1998 dalam Mar'ah Mujahidah, 2018. Mengidentifikasi lima fungsi dasar dari keluarga diantaranya ialah: Fungsi afektif (The Affective Function) Fungsi afektif berkaitan dengan fungsi internal dalam keluarga yang merupakan basis kekuatan dari keluarga. Fungsi afektif berguna untuk pemenuhan kebutuhan psikologis. Keberhasilan fungsi afektif tampak melalui keluarga yang gembira dan bahagia. Dukungan (reinforcment) yang semuanya dipelajari serta dikembangkan secara interaksi dalam keluarga. Fungsi sosialisai (the socialization function) Sosialisai dimulai pada saat lahir dan akan diakhiri dengan kematian. Sosialisai ialah suatu proses yang berlangsung dalam seumur hidup, dimana individu secara kontinu dapat mengubah perilaku mereka sebagai respon terhadap sesuatu yang terpola dengan cara sosial yang mereka alami. Fungsi Reproduksi (the reproductive function) Keluarga berfungsi untuk meneruskan kelangsungan keturunan dan menambah sumber daya manusia. Dengan adanya program keluarga berencana, maka dari itu fungsi ini sedikit terkontrol. Namun disisi lain banyak juga kelahiran yang tidak diharapkan atau dibilang kehamilan diluar ikatan pernikahan, sehingga lahirlah keluarga baru dengan orang tua tunggal. Fungsi ekonomi (the economic function) Untuk memenuhi kebutuhan seperti: makanan, pakaian, dan tempat tinggal, maka dari itu keluarga memerlukan sumber keuangan. Fungsi ini sulit dipenuhi oleh keluarga yang berbeda dibawah garis kemiskinan. Menurut (keliat, 2011 dalam Aprillina Kartini, 2017). Kecemasan adalah perasaan was-was seakan sesuatu yang buruk akan terjadi dan merasa tidak nyaman seakan ada ancaman yang disertai gejala-gejala fisik seperti jantung yang berdebar,keringat dingin dan tangan yang gemetar.

Menurut asumsi peneliti, peran keluarga di wilayah RW. 01 Kelurahan Kukusan Kecamatan Beji Kota Depok, peran keluarga terhadap lansia kurang baik karena komunikasi yang kurang dan kesibukan yang menjadikan alasan kenapa keluarga kurang berperan aktif dalam peran keluarga terhadap lansia sehingga mempengaruhi tingkat kecemasan pada lansia dimana keluarga yang terus memberikan perhatian penuh kepada lansia akan membuat lansia merasa dirinya dihargai dan diinginkan sehingga tingkat kecemasannya akan stabil .

\section{Kesimpulan}

Peran keluarga pada lansia di wilayah RW. 01 Kelurahan Kukusan Kecamatan Beji Kota Depok mayoritas dikatakan kurang baik. Tingkat kecemasan di wilayah RW. 01 Kelurahan Kukusan Kecamatan Beji Kota Depok mayoritas dikatakan sedang. Ada hubungan Peran Keluarga dengan Tingkat Kecemasan Lansia di Wilayah RW. 01 Kelurahan Kukusan Kecamatan Beji Kota Depok.

\section{Konflik Kepentingan}

Peneliti menyatakan bahwa penelitian ini independen dari konflik kepentingan individu dan organisasi.

\section{Ucapan Terima Kasih}

Terimakasih kepada seluruh pihak yang telah berkontribusi membantu proses penelitian ini.

\section{Pendanaan}

Sumber pendanaan diperoleh dari peneliti. 


\section{Daftar Pustaka}

1. Boedhi-Darmojo R, Hadi-Martono H. Teori Proses Menua. In: Hadi-Martono H, Pranarka K, editors. Ilmu Kesehatan Usia Lanjut. Jakarta: Badan Penerbit FKUI; 2014.

2. World Health Organization; 2010

3. Badan Pusat Statistik; 2011.

4. Badan Pusat Statistik; 2015.

5. Maryam. mengenal usia lanjut dan perawatannya. Jakarta: Salemba Medika; 2011.

6. Rahayu, S. Keperawatan Keluarga. Yogyakarta : Graha Ilmu; 2008.

7. Friedman. Buku Ajar Keperawatan Keluarga teori dan praktik. Jakarta: EGC; 2010.

8. Touhy, Theris A. Ebersole and Hess Gerontological Nursing and Healthy aging. USA: Elsevier; 2014.

9. Silalahi U. Metode dan Metodologi Penelitian. Bina Budhaya; 1999.

10. Nugroho. Keperawatan gerontik \& geriatrik, edisi 3. Jakarta : EGC; 2012.

11. Harnilawati. Konsep dan proses Keperawatann Keluarga. Sulawesi Selatan: Pustaka As Salam; 2013.

12. Anggraini, D. Perbandingan Kepuasan Pasien Gakin dan Pasien Umum di Unit Rawat Inap RSUD Budhi Asih Tahun 2008.Skripsi. Program Sarjana Fakultas Kesehatan Masyarakat Universitas Indonesia, Depok; 2008.

13. Kartini, A. hubungan tingkat kecemasan dengan kejadian insomsia pada lansia di unit pelayanan terpadu puskesmas wilayah citereup. Bogor: Sekolah Tinggi Ilmu Kesehetan Indonesia Maju; 2017.

14. Kartini, A. hubungan tingkat kecemasan dengan kejadian insomsia pada lansia di unit pelayanan terpadu puskesmas wilayah citereup. Bogor: Sekolah Tinggi Ilmu Kesehetan Indonesia Maju; 2017.

15. Hidayati , Laili Nur. Hubungan Dukungan Sosial Dengan Tingkat Depresi Pada Lansia Di Kelurahan Daleman Tulung Klaten. Skripsi. Tidak diterbitkan. Surakarta : Keperawatan S1 Fakultas ilmu kesehatan UMS; 2009.

16. Harnilawati. Konsep dan proses Keperawatann Keluarga. Sulawesi Selatan: Pustaka As Salam; 2013. 